\title{
Callus Age and Size of Barley (Hordeum vulgare L.) Improves Regeneration Efficiency
}

\author{
Mozidul HAQUE, SM Shahinul ISLAM* \\ Plant Genetic Engineering Lab, Institute of Biological Sciences, Third Science Building, University of Rajshabi, Rajshabi-6205, \\ Bangladesh;mozidulbot@gmail.com;shahin_ibsc@ruac.bd("correspondingauthor)
}

\begin{abstract}
In order to improve regeneration efficiency embryos derived from immature seeds of BARI barley-6 were taken for this study. In this case callus size, age and its fresh weight were considered. Embryos sizes were classified into four groups: 0.6-1.0 mm (A), 1.1-1.5 mm (B), 1.6-2.0 $\mathrm{mm}(\mathrm{C})$ and 2.1-2.5 $\mathrm{mm}(\mathrm{D})$, and cultured to semi-solid MS medium for callus induction. Five weeks old calli were transferred to MS medium that contained $1.0 \mathrm{mg} / \mathrm{l} \mathrm{BAP}+150 \mathrm{mg} / \mathrm{L}$-glutamine, for regeneration. Results indicated that 1.6-2.0 mm size of embryos produced the highest callusing $(56.72 \%)$ and green plantlets $(42.16 \%)$, while small sized $(0.6-1.0 \mathrm{~mm})$ showed very poor $(2.75 \%)$ callusing and no regeneration occurred. Calli were divided into three age groups e.g. early ( $1-3$ weeks), medium ( $4-6$ weeks) and prolonged age (7-12 weeks) and cultured to regeneration medium. To observe the effect of calli weight on regeneration, they were grouped into four categories: I (50-100 mg), II (101-150 mg), III (151-200 mg) and IV (>201 mg). The highest regeneration and rooting were recorded when the age of callus was 46 weeks and its weight range was $151-200 \mathrm{mg}$ (III). The lowest regeneration and rooting were found when 1-3 weeks old calli were used and its average weight was $50-100 \mathrm{mg}(\mathrm{I})$.
\end{abstract}

Keywords: barley, callus age and weight, embryo size, in vitro, regeneration

\section{Introduction}

Barley (Hordeum vulgare L.) is one of the important cereals in the world and among the oldest domesticated crop (Jakob $e t$ al., 2014). Today, barley represents the fourth most abundant cereal both in area of cultivation and in grain output (FAOSTAT, 2014). It is regarded as an inferior staple compared to wheat and is considered as the poor people's bread. Economically, barley is a major commodity in many European and North African countries (Elsayed, 2013).

In recent years, advances in plant biotechnology have opened new avenues for crop improvement. The success of in vitro development of plants relies on several factors which include an efficient tissue culture system, for regeneration of plants from cultured cells and tissues (Khatun et al. 2012; Kumar et al., 2009). Successful callus induction and regeneration has been dependent of using efficient explants and different pretreatments factors that are also influencing somatic and gametic embryogenesis in many cereal crops (Farshadfar et al., 2014; Hussein et al., 2003; Islam and Tuteja, 2012; Rakshit et al., 2010). However, regeneration ability is strongly affected by several factors such as genotypes, developmental stages and composition of culture medium and type of explants (Gubišová et al., 2012; Haque and Islam, 2014; Siddique et al., 2014). Different explants are used for efficient callus induction and its subsequent regeneration e.g. immature embryos (Chang et al., 2003), immature inflorescence (Havrlentova et al., 2001), mature embryo (Abumhadi et al., 2005). Age of callus and embryo size are also playing an important role on regeneration as reported by Saad et al. (2004), Senarath (2007) and Islam (2010).

As far as we know there is no report on plant regeneration using age groups of callus and immature embryo sizes for developing in vitro somatic embryogenesis on barley. Under this study, using embryos size derived immature seeds, callus age and their weight have been considered for improving regeneration systems in barley, for advance biotechnological research.

\section{Materials and methods}

\section{Plantmaterial}

Healthy and mature viable seeds of BARI barley- 6 were collected from Bangladesh Agricultural Research Institute (BARI), Gazipur, Bangladesh. In order to obtain immature embryos, seeds were grown in the experimental field of Institute of Biological Sciences, University of Rajshahi. Spikes were harvested from main tillers of post anthesis levels from field grown plants and immature embryos were separated carefully from 14 days of old spikes.

\section{Sterilization of seeds}

Seeds were surface sterilized with $70 \%$ ethanol for 2 minutes and rinsed 4-5 times with sterile distilled water. Then seeds were treated with $5 \%$ sodium hypochlorite for 30 minutes and washed with sterile distilled water 5-6 times under laminar air-flow cabinet. Immature embryos were aseptically isolated from the immature seeds with a sterile scalpel. 
Embryo size effects on callus induction and regeneration

The effect of the size of embryos: (A) 0.6-1.0 mm, (B) 1.1$1.5 \mathrm{~mm},(\mathrm{C}) 1.6-2.0 \mathrm{~mm}$ and (D) $2.1-2.5 \mathrm{~mm}$, on callus induction and plant regeneration was studied for immature embryos derived from seeds. The embryos of each size were cultured on MS (Murashige and Skoog, 1962) medium supplemented with $2.0 \mathrm{mg} / \mathrm{l}$ 2, 4-D, $200 \mathrm{mg} / \mathrm{l}$ L-glutamine and incubated in dark chamber at $25 \pm 2{ }^{\circ} \mathrm{C}$. The $\mathrm{pH}$ of the medium was adjusted at 5.6-5.8. When the calli ages were around four weeks old, they were transferred to regeneration medium (MS $+1.0 \mathrm{mg} / \mathrm{l} \mathrm{BAP}+150 \mathrm{mg} / \mathrm{l} \mathrm{L}$-glutamine) and cultured under low light conditions at $25 \pm 2{ }^{\circ} \mathrm{C}$ together with $14 / 10 \mathrm{hrs}$ (light/dark) photoperiods. Data on callusing was recorded after four weeks of immature seeds inoculation and regeneration frequency was recorded after eight weeks of culture, respectively.

\section{Effects of callus age and weight on regeneration}

To observe regeneration efficiency of callus age and its fresh weight calli were divided into three age groups: early (13 weeks), medium (4-6 weeks) and prolonged duration (7-12 weeks). After callus initiation, they were cultured to the same medium for regeneration (MS $+1.0 \mathrm{mg} / \mathrm{l} \mathrm{BAP}+150 \mathrm{mg} / \mathrm{l} \mathrm{L}$ glutamine). When the calli ages were around five weeks old, the calli were individually weighted and grouped into four categories: I (50-100 mg), II (101-150 mg), III (151-200 mg) and IV $(>201 \mathrm{mg})$. Each callus were weighted individually and for each group around 25-75 numbers of callus were taken. Five weeks old calli were considered for callus weight. Then cultures were incubated around twelve weeks at $25 \pm 1$ ${ }^{\circ} \mathrm{C}$ with a 16/8 hr (light/dark) photoperiod, for callus induction.

\section{Rooting and acclimatization of regenerated plants}

Regenerated shoots were transferred to GM (Islam, 2000) medium supplemented with $1.0 \mathrm{mg} / \mathrm{l} \mathrm{IAA}$ and $20 \mathrm{~g} / \mathrm{l}$ sucrose. For rooting, $3 \mathrm{~g} / \mathrm{l}$ phytagel were used as gelling agent. Well rooted plantlets were transferred to pots that contained peat moss and soil (1:1). To evaluate the root formation, average number of roots per plants were recorded and calculated.

\section{Data recording and statistical analysis}

For each treatment, three replications were evaluated and each experiment was repeated three times. Statistical analysis of the data was performed by SPSS software (version 16). A one-way analysis of variance (ANOVA) was done to evaluate the effect of callus age and weight on regeneration. Within the treatment groups, the differences among means were compared by Duncan's multiple range tests (DMRT).

\section{Results and discussions}

In this study, the effects of callus age, fresh weight of callus and their interactions on regeneration and rooting traits were tested. Stages of callus development and their subsequent regeneration are illustrated in Fig. 1 .

\section{Effects of embryo size on callus induction and regeneration}

To observe the effect of the size of embryos upon regeneration, immature embryos derived from seeds were classified into four groups and recorded data were shown in Fig. 2. It was observed that the size of $1.6-2.0 \mathrm{~mm}(\mathrm{C})$ showed
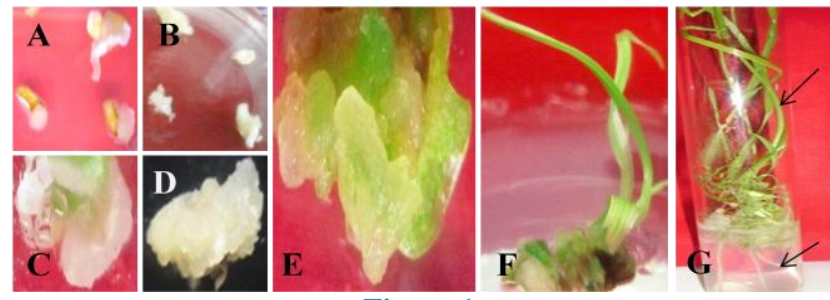

Fig. 1. Stages of callus development and regeneration from immature embryos in barley. (A) Callus initiation after 3 weeks of culture. (B) Callus after 1-3 weeks of callus initiation. (C) Callus after $4-6$ weeks of callus initiation. (D) Callus after 7-12 weeks of callus initiation. (E) Callus with green structures. (F) Development of shoots. (G) Regenerated plants with good root and shoots.

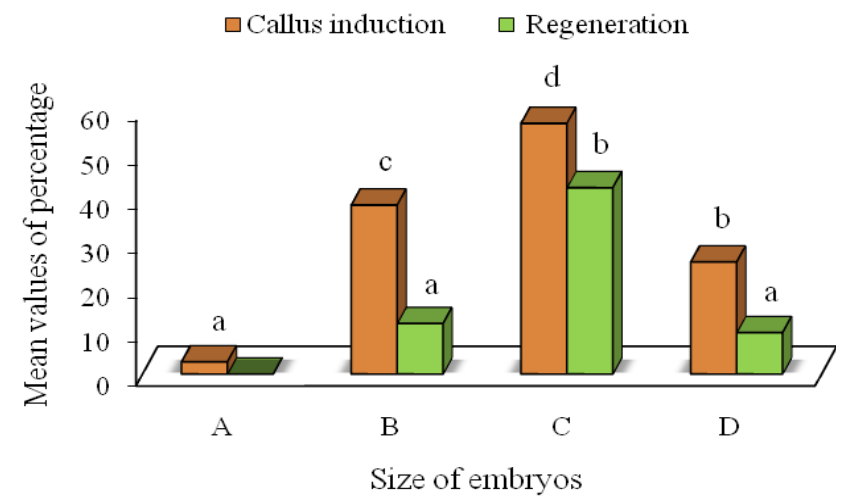

Fig. 2. Comparison of callus induction and regeneration among the different sizes of immature embryos $(\mathrm{P}<0.05) ; \mathrm{A}=0.6-1.0 \mathrm{~mm}, \mathrm{~B}=$ $1.1-1.5 \mathrm{~mm}, \mathrm{C}=1.6-2.0, \mathrm{D}=2.1-2.5 \mathrm{~mm}$ size of embryos

significantly the highest percentage of callus induction as well as plant regeneration. The highest frequencies were recorded as $56.83 \%$ and $42.31 \%$ for callus induction and plant regeneration respectively, when $1.6-2.0 \mathrm{~mm}(\mathrm{C})$ embryo size was used whereas $0.6-1.0 \mathrm{~mm}$ in length showed less $(2.85 \pm 0.56)$ callus induction and no regeneration was found. It was observed that when the embryo size was $2.1-2.5 \mathrm{~mm}$ regeneration decreased.

The present results on the influence of embryo size on callus induction and regeneration agreed well with the findings of Senarath (2007), Jakubeková et al. (2011). Senarath (2007) mentioned that embryos of $1.6-2.0 \mathrm{~mm}$ showed the highest ability to produce callus capable of regenerating green plants. The percentage of primary and embryogenic callus formed from immature embryos of 3-4 mm was lower than that formed from 1-2 mm long embryos in maize (Jakubeková et al. 2011). This was probably due to a reduction in the meristematic activity of cells once with ageing, suggesting that the physiological and developmental state of immature embryos is important in determining callus initiation response. Bohorova et al. (1995) reported that maize embryo less than $0.5 \mathrm{~mm}$ in length did not showed any plant regeneration. Similar types of results were found by Lu et al. (1983) when they used embryo size less than 1 $\mathrm{mm}$ in maize. Whereas, barley embryos $(0.5 \mathrm{~mm}$ to $2.0 \mathrm{~mm})$ and $(0.7 \mathrm{~mm}$ to $1.77 \mathrm{~mm})$ in length produced rapidly growing callus with high frequency of plant regeneration (Dale and Deambrogio, 1979; Hanzel et al., 1985). However, it differs from the observation of Islam (2010), where more green plantlets were produced from large $(>2.0-3.0 \mathrm{~mm})$ embryos in the case of wheat anther culture, which is different than the findings within the present results. Indra and Krishnaveni (2009) observed that 
Table 1. Effect of age and fresh weight of callus derived from immature embryos on plant regeneration and rooting

\begin{tabular}{lcccc}
\hline $\begin{array}{l}\text { Fresh weight } \\
\text { of callus (mg) }\end{array}$ & $\begin{array}{c}\text { Age of } \\
\text { callus (weeks) }\end{array}$ & No. of callus & \multicolumn{2}{c}{ Mean of percentage \pm S.E } \\
\cline { 4 - 5 } Group-I & $1-3$ & 25 & Regeneration & Rooting \\
\cline { 3 - 4 }$(50-100)$ & $4-6$ & 25 & $5.33 \pm 1.33$ & $22.66 \pm 3.52$ \\
& $7-12$ & 25 & $9.33 \pm 2.66$ & $18.66 \pm 3.52$ \\
\hline \multirow{2}{*}{ Group-II } & $1-3$ & 75 & $10.22 \pm 1.60$ & $8.66 \pm 1.33$ \\
$(101-150)$ & $4-6$ & 75 & $32.88 \pm 2.70$ & $24.44 \pm 2.70$ \\
\hline \multirow{2}{*}{ Group-III } & $7-12$ & 75 & $13.77 \pm 1.93$ & $10.22 \pm 1.60$ \\
$(151-200)$ & $1-3$ & 75 & $21.77 \pm 2.47$ & $17.33 \pm 2.30$ \\
& $4-6$ & 75 & $62.66 \pm 4.28$ & $53.77 \pm 3.20$ \\
Group-IV $(201>)$ & $7-12$ & 75 & $34.22 \pm 3.47$ & $23.55 \pm 3.11$ \\
& $1-3$ & 50 & $15.33 \pm 1.76$ & $11.33 \pm 0.66$ \\
\hline
\end{tabular}

Table 2. ANOVA for the effect of age and fresh weight of callus on plant regeneration and rooting

\begin{tabular}{lccccc}
\hline \multirow{2}{*}{ Source of Variation } & \multirow{2}{*}{ df } & \multicolumn{2}{c}{ Regeneration } & \multicolumn{2}{c}{ Rooting } \\
\cline { 3 - 6 } & & MS & F. value & MS & F. value \\
\hline Callus weight & 3 & 1205.84 & $65.31^{* *}$ & 797.597 & $48.503^{* *}$ \\
Callus age & 2 & 2571.07 & $139.26^{* *}$ & 1795.33 & $109.176^{* *}$ \\
Callus age $\times$ weight & 6 & 88.40 & $4.78^{* *}$ & 83.624 & $5.085^{* *}$ \\
Error & 24 & 18.46 & & 16.444 & \\
\hline${ }^{* *}$ Significant at $\mathrm{P}<0.01$ & & \multicolumn{4}{c}{}
\end{tabular}

$0.8-1.4 \mathrm{~mm}$ size of embryos yielded more embryogenic calli in sorghum. Gugsa and Kumlehn (2011) demonstrated intermediate sized (0.2-0.35 mm) embryos of tef (Eragrostis tef) produced significantly more root and shoots than the small $(0.1$ $0.2 \mathrm{~mm})$ or large $(0.35-0.75 \mathrm{~mm})$ ones.

\section{Effect of age and fresh weight of callus on shoots and roots development}

In the current experiment it was observed that the fresh weight 151-200 mg (III) of callus showed significantly the highest percentage of green plantlets and roots (Table 1). Whereas small 50-100 $\mathrm{mg}$ (I) and large (>201 mg) (IV) weight showed less regeneration and roots. Moreover, when the calli were transferred to regeneration medium within 46 weeks (medium age), they showed significantly a higher percentage of green plantlets along with good shoots and roots. But when early (1-3 weeks) and prolonged aged (7-12 weeks) calli were transferred to regeneration medium, plant regeneration decreased. Among the different callus ages and fresh weights, the callus weight of 151-200 mg(III) and the callus age of 46 weeks (medium age) showed better regeneration $(62.66 \%)$ and rooting (53.77\%).

The effects of callus age, fresh weight of callus and their interactions on regeneration and rooting were tested at $\mathrm{P}<0.01$ level of significance by F-test (Table 2) and were found to be highly significant.

Generally, calli with earlier ages have more totipotency as compared to old ages calli, as reported by Rashid et al. (1994). Quainoo (2011) demonstrated that somatic embryos induced from callus tissues aged between 48 weeks showed no viral infection in cocoa shoots, but the virus infected the somatic embryos induced from older callus tissues. In this study, it was observed that the best age group for regeneration as well as rooting was that of 34 weeks. One to two weeks old calli was either too small or fragile that they cannot survive, so their regeneration and rooting frequency is lesser (Raja et al., 2009). On the other hand, 5-6 weeks old callus has lost their regeneration and rooting ability, possible due to repeated cell divisions. Therefore, it was clearly demonstrated that medium age of callus transferred into regeneration medium within 46 weeks was more efficient for plant regeneration in comparison with earlier ages (1-3 weeks) or prolonged culture (7-12 weeks). Similar type of result was reported for wheat by Raja et al. (2009), who observed that the best age for regeneration was between 22 to 30 days old calli. Similarly, Islam (2010) reported that an early transfer of embryos into the regeneration medium, within threefive weeks, was more efficient for regeneration of green plantlets in comparison to prolonged culture (6-8 weeks) in wheat anther culture.

It was also found that the fresh weight of callus influenced the regeneration efficiency. Callus weight of $151-200 \mathrm{mg}$ (III) yielded more plantlets than other fresh weights of the same age calli. Furthermore, the roots of the plants were strong and healthy when 151-200 mg (III) weight and the 46 weeks (medium age) old callus was cultured. Therefore, the registered data proved that callus age and fresh weight are important factors for the production of increased plantlets and roots in barley.

\section{Conclusions}

The successes of in vitro development of plants derived from different organs are dependents on several factors such as explants sources, callus quality, shape, size, age of embryos, media, growth regulators etc. Considering age groups of callus and embryo sizes derived from seeds, till day there are no successful reports on barley. Under this study it was successfully developed a suitable protocol on regeneration. Embryos size, callus age and their weight were evaluated for improving regeneration efficiency, with important and helpful data for biotechnological research in barley and other cereal crops. Under this study, the highest callusing and most green plants were obtained when $1.6-$ $2.0 \mathrm{~mm}$ size of embryos were used. Out of the four aged groups, 4-6 weeks old calli, and when its weight range was 151-200 mg, showed better performance on green plant regeneration. From these findings it may be concluded that for a good barley regeneration, callus size, age and its fresh weights are important factors for increasing green plantlets as well as root development. 


\section{Acknowledgements}

The authors are gratefully acknowledges to Plant Genetic Engineering Lab., Institute of Biological Sciences, University of Rajshahi for providing research facilities and the University Grant Commission (UGC) of Bangladesh for providing fellowships for this study.

\section{References}

Abumhadi N, Kamenarova K, Todorovska E, Dimov G, Trifonova A, Gecheff K, Atanassov A (2005). Callus induction and plant regeneration from barley mature embryos (Hordeum vulgare $\mathrm{L}$.). Biotech Biotechnol 19(3):32-38.

Bohorova NE, Luna B, Brito RM, Huerta LD (1995). Regeneration potential of tropical, subtropical, midaltitude and highland maize inbeds. Maydica 40:275-281.

Chang Y, Von Zitzewitz J, Hayes PM, Chen THH (2003). High frequency plant regeneration from immature embryos of an elite barley cultivar (Hordeum vulgare L. cv. Morex). Plant Cell Rep 21:733-738.

Dale PJ, Deambrogio E (1979). A comparison of callus induction and plant regeneration from different explants of Hordeum vulgare. Zeitschriff für Pflanzenphysiologie 94:65-77.

Elsayed EM (2013). Analysis of the efficiency in the Spanish national barley breeding program. Past results and prospects for future improvements using molecular markers. $\mathrm{PhD}$ Thesis, University of Lleida, Spain.

Farshadfar E, Jamshidi B, Chehri M (2014). Assessment of immature embryo culture to select for drought tolerance in bread wheat. International Journal of Biosciences 4:194203.

FAOSTAT (2014). Food and Agriculture Organization of the United Nations. Statistics Division. Online available at http://faostat.fao.org.

Gubišová M, Mihálik D, Gubišj (2012). Optimization of barley mature embryo regeneration and comparison with immature embryos of local cultivars. Nova Biotechnologicaet Chimica 11(1):57-62.

Gugsa L, Kumlehn J (2011). Somatic embryogenesis and massive shoot regeneration from immature embryo explants of tef. Biotech Res Int 2011:1-7.

Hanzel JJ, Miller JP, Brinkman MA, Fenods E (1985). Genotype and media effects on callus formation and regeneration in barley. Crop Sci 25:27-31.

Haque M, Islam SMS (2014). Enhancement of anther culture response by cold pretreatment and optimization of media about two barley genotypes derived from Bangladesh. As Pac J Mol Bio Biotech 22(1):127-136

Havrlentova M, Farago J, Nestakova M (2001). Regeneration of immature inflorescences of barley. In Vitro Cell Dev Biol-Plant 44:157-159.

Hussein EHA, Madkour MA, Assem SK, Radwan AMA (2004). Embryogenic callus formation and plant regeneration from immature embryos of some barley genotypes (Hordeum vulgare L.). ArabJ Biotech 7(1):111-122.
Indra AP, Krishnaveni S (2009). Effect of hormones, explants and genotypes in in vitro culturing of Sorghum. J Biochem Tech 1(4):96103.

Islam SMS (2000). Anther and microspore culture of wheat (Triticum aestivum $\mathrm{L}$.). PhD. dissertation. University of Rajshahi, Bangladesh.

Islam SMS (2010). Effect of embryoids age, size and shape for improvement of regeneration efficiency from microspore-derived embryos in wheat (Triticum aestivum L.). Plant Omics J 3(5):149153.

Islam SMS, Tuteja N (2012). Enhancement of androgenesis by abiotic stress and other pretreatments in major crop species. Plant Sci 182:134-144.

Jakob SS, Rödder D, Engler JO, ShaafS, Özkan H, Blattner FR, Kilian B (2014). Evolutionary history of wild barley (Hordeum vulgare subsp. spontaneum) analyzed using multilocus sequence data and paleodistribution modeling. Genome Biol Evol 6:685-702.

Jakubeková M, Pretová A, Obert B (2011). Somatic embryogenesis and plant regeneration from immature embryo induced callus of Maize (Zea mays L.).J Microbiol Biotech Food Sci 1(4):478-487.

Khatun R, Islam SMS, Ara I, Tuteja N, Bari MA (2012). Effect of cold pretreatment and different media in improving anther culture response in rice (Oryza sativa L.) in Bangladesh. Indian J Biotech 11(4):458-463.

Kumar V, Parvatam G, Ravishankar GA (2009). $\mathrm{AgNO}_{3}$ A potential regulator of ethylene activity and plant growth modulator. Electron J Biotech 12:1-15.

Lu C, Vasil V, Vasil IK (1983). Improved efficiency of somatic embryogenesis and plant regeneration in tissue cultures of maize (Zea mays L.). Theor Appl Genet 66:285-289.

Murashige T, Skoog F (1962). A revised medium for rapid growth and bioassays with tobacco tissue cultures. Physiol Plantarum 15:473-497.

Quainoo AK (2011). Age of callus tissues and cotyledonary materials on the selection of cocoa swollen shoot virus-free somatic embryos. Reseat Biotechnol 2(2):75-81.

Raja NI, Bano A, Rashid H, Khan MH, Chaudhry Z (2009). Effect of age of embryogenic callus on plant regeneration in local cultivars of wheat (Triticum aestivum L.). PakJ Bot 41(6):2801-2806.

Rakshit S, Rashid Z, Sekhar JC, Fatma T, Dass S (2010). Callus induction and whole plant regeneration in elite Indian maize (Zea mays L.) inbreds. Plant Cell Tiss Org Cult 100:31-37.

Rashid H, Hameed S, Chaudhry Z, Thair F, Qurashi A (1994). Quantitative protein from embryogenic and non-embryogenic calli. Agri Res 15(1):97-99.

Saad IM, Rashid H, Yasmin T, Minhas NM (2004). Plant regeneration by somatic embryogenesis from callus of mature seed explants of bread wheat (Triticum aestivumL.). PakJ Bot 36(3):629-634.

Senarath WTPSK (2007). High frequency plant regeneration from immature embryos of an elite barley cultivar (Hordeum vulgare $\mathrm{L} \mathrm{cr}$ Baegdong).J Nat Sci Found Sri Lanka 35:161-165.

Siddique AB, Ara I, Islam SMS, Tuteja N(2014). Effect of air desication and salt stress factors on in vitro regeneration of rice (Oryza sativa $\mathrm{L}$.). Plant Signaling \& Behavior9(12) e977209. 